\title{
When old becomes new: A case study of oral examination as an online assessment tool
}

\author{
Alexandr Akimov* and Mirela Malin \\ Griffith Business School, Griffith University, Southport, Australia \\ Address: Griffith University, Parklands Drive, Southport 4222 Australia
}

Email: a.akimov@griffith.edu.au

\author{
Biographical Notes
}

Alexandr Akimov

Dr Alexandr Akimov is a Senior Lecturer in Banking and Finance at Griffith University. He holds a $\mathrm{PhD}$ in Financial Economics from the University of New England, as well as CFA and ERP professional designations. In addition to academic appointments, Alexandr has held risk management positions at the National Bank of Uzbekistan. He is an active member of a number of professional and research associations.

His research expertise is in the areas of emerging market finance, energy and carbon markets, local government finance, and financial education. As an educator focusing on evidence-based solutions to practical educational problems, Dr Akimov has been the recipient of a number of university citations for excellence in teaching.

\section{Mirela Malin}

Dr Mirela Malin is a Senior Lecturer in Finance at Griffith University. She holds a Bachelor's in Business (Accounting), a Bachelor's in International Finance (Honours), and a PhD from Griffith University. She has a research interest in how technology has influenced teaching in higher education and how blended learning techniques have been used to enhance student learning outcomes.

Dr Malin has presented at blended learning symposiums and international teaching conferences, and has been a reviewer for journals and conferences in education and finance. Her publications include articles in the Journal of International Financial Markets, Institutions \& Money, the Quarterly Review of Economics and Finance, Accounting Research Journal, and the Journal of Financial Education.

* Dr Akimov is the corresponding author for this paper and can be contacted at:

a.akimov@griffith.edu.au 
Alexandr Akimov:

ORCiD: 0000-0002-1977-1476, https://orcid.org/0000-0002-1977-1476

LinkedIn: https://www.linkedin.com/in/alexandr-akimov-aa983126

Mirela Malin:

ORCiD: 0000-0002-9338-3703, http://orcid.org/0000-0002-9338-3703

LinkedIn: https://www.linkedin.com/in/mirela-malin-a1b9b113/

Twitter:@MirelaMalin 


\section{Abstract}

Assessment is an important element of any effective teaching and learning strategy. Designing an appropriate assessment strategy is a continual challenge for instructors because the assessment structure must be well aligned with the intended learning outcomes. Technological advances have led to an expansion of online and distance modes of course delivery and brought new challenges, such as accessibility and legality, identity security and academic dishonesty. This study describes the application of an oral examination as a form of assessment in the online context. The findings demonstrate that oral examination can assist in overcoming some of the challenges associated with online learning. However, careful planning is required to ensure that it meets the principles fundamental to a successful assessment strategy: validity, reliability and fairness.

Keywords: oral examination, online, assessment, financial education, academic dishonesty. 


\section{Introduction}

One of the significant elements in any teaching and learning environment is assessment. It is well known that what students learn and how they go about it is influenced by how they think they will be assessed (Biggs and Tang 2007). Although the practice of assessing learners is not new, the development of assessment is a continual challenge for instructors. That challenge has become more pronounced as education providers have embraced online and distance modes of delivery, where the traditional ways of teaching, learning and assessing have had to be redesigned to reflect the pedagogy of online learning (Akimov, Kobinger, and Malin 2018).

Although traditional strategies for the design and implementation of teaching and assessment are still valid and critical for effective learning, the online environment has created new demands and emphasis on the development of content appropriate to the medium. Not only should assessment adhere to the principles of validity, reliability and fairness, but it should also involve multiple measurements, and include both formative and summative tasks (Hargreaves 2007; Oosterhof, Conrad, and Ely 2008). Furthermore, when designing online assessments, instructors must also take into consideration issues of accessibility and legality, identity security, and academic integrity. These requirements are particularly relevant for institutions that seek accreditation from professional and educational bodies.

This paper provides an insight into a well-known but underutilised form of online assessment - the oral examination. This form of assessment has been implemented mainly in the face-to-face environment for doctoral examinations or as part of practical examinations in the medical field. Although there are some studies that document oral examination in the business areas of marketing and tourism (Pearce and Lee 2009), limited research has been conducted on the use of oral examination in more technical courses (Bhati 2012; Iannone and Simpson 2012; Rawls, Wilsker, and Rawls 2015). Moreover, the literature that discusses oral 
examination in an online context is practically non-existent. This paper adds to the body of research in the area of online education by investigating the use of oral examinations in a course delivered fully online. The research questions guiding this study focus on 'Whether oral examinations can be adopted as an effective and authentic assessment in an online context' and 'What perceptions students have of the applicability and effectiveness of an online oral examination'.

A review of relevant literature follows. First, the existing literature on oral examination in a broader context is introduced. Then, the contemporary challenges of online assessment are outlined, followed by a discussion of whether oral examinations could address some of the challenges in online assessment. The case study and the setting for the authentic assessment strategy investigated in this research are described next, followed by a discussion in which the experience of implementation and student perceptions of oral examination are presented. An evaluation of the experiment and final remarks conclude the paper.

\section{Oral assessment evaluation}

The ability to communicate effectively is one of the skills that higher education students must possess to be successful in today's competitive and global work environment. In addition to having the necessary technical skills for a profession, employers also demand that graduates can present information in a clear and articulate manner to a variety of audiences (MurilloZamorano and Montanero 2018). Thus, it is important that oral communication skills be assessed through a variety of formative or summative oral assessment tasks that also contribute to the process of learning.

Joughin (2010) organises oral assessment into: presentations on a particular topic or on group work; interrogations in which students are questioned by examiners or a panel; applications in which students are assessed in terms of diagnosis and recommended actions in a simulated clinical environment. Further, oral assessment can also be classified into 
assessment that evaluates communication and language skills, and assessment that examines problem-solving, critical thinking and students' ability to demonstrate their mastery of content and concepts (Kehm 2001; Borin, Metcalf, and Tietje 2008). Educators should clearly understand the role, significance and purpose of an oral assessment in order to design adequate assessments that test the appropriate learning outcomes. This paper investigates oral assessment in the form of 'interrogation', in which students are questioned and crossexamined by faculty to determine their levels of problem-solving and critical thinking in relation to specific technical content, and also evaluates appropriate business communication skills.

Joughin (1998) identifies six principal attributes of oral assessment: primary content type (whether the learning being assessed represents knowledge and understanding, or the application of problem-solving abilities); interaction (the interchange between examiner and student); authenticity (the extent to which the assessment relates to professional practice); structure (for example, an organised, predetermined body of questions or events); examiners (whether an individual, panel or peers); degree of orality (whether assessment is purely oral or secondary to another form of assessment). From the perspective of either a teacher or an educational researcher, these dimensions are also useful in identifying issues associated with the validity and reliability of oral assessment.

An assessment is valid when it allows students to demonstrate their knowledge, skills and values in relation to a course they are studying. The concept of validity can be further expanded to ensure that an assessment includes 'face validity' (the assessment tests what it is supposed to test), 'content validity' (the assessment covers the field being studied), 'construct validity' (the assessment of underlying graduate outcomes) and 'concurrent validity' (whether performance is consistent among different tasks that measure the same learning outcome). Although validity is deemed to be one of the strongest features of oral assessment, reliability 
might be regarded as a weak element of it. When addressing the reliability of oral assessments, instructors must consider whether the student would perform equally well if: (i) other questions were to be asked (inter-case reliability); (ii) there is opportunity to respond on a different scenario or follow-up questions (inter-item consistency); (iii) the questions were asked by different assessors (inter-rater reliability); (iv) the examiner's judgement is the same at various points in time during the assessment process (intra-rater reliability) (Joughin 2010, 13-14). Reliability can be improved if students are assessed on multiple cases, there is a large pool of questions, and a panel of assessors is involved.

The literature surveyed shows that implementing oral examination in an assessment strategy has led to enhanced communication skills, knowledge and confidence among students, has increased their motivation to learn and understand the subject matter, and has decreased their likelihood of cheating. However, major hurdles have prevented oral examination being more widely adopted, including the high level of anxiety and stress experienced by students, the planning, resources and time spent by faculty on conducting the examinations, and the reliability, validity, objectivity and perceived examiner biases associated with oral examination. Table 1 summarises the existing literature that has considered various forms of oral assessment, highlighting the benefits and challenges encountered in their implementation across different fields.

[Insert Table 1 near here]

\section{Assessment strategies in the online environment}

In combination with the changing preferences in the way students engage with their learning, technological advances have led to an increased demand for online education. As a result, existing traditional assessment techniques need to be modified to reflect the nature of online pedagogy (Robles and Braathen 2002) and to address the removal of the normal faceto-face interaction and observation of the classroom (Benson 2003). Measuring knowledge in 
the online environment demands the use of appropriate synchronous and asynchronous assessment tools, as well as making learning visible in such a way that there is observable evidence of that learning (Oosterhof, Conrad, and Ely 2008). Whether it is considered formative or summative - and depending on the level of authentication, security and supervision - online assessments range from quizzes, discussion boards/blogs, video presentations, peer assessments, simulations/games and essays/reports, to ePortfolios, bringyour-own-device (BYOD) eExams, and remote or in-house proctored eExams (Rovai 2000; Dawson 2016; Xiong and Suen 2018; Fluck 2019). This expansion in the options available for testing student knowledge has resulted in both benefits and challenges for the assessment of learning in the online environment.

Supporters of online examinations argue that higher-order thinking skills can be tested via scenario-based or open-ended questions, simulations using discipline-specific professional software, and the use of multimedia, thus providing authentic assessments that prepare students for their working life (Lim et al. 2006; Rytkönen and Myyry 2014; Peet 2016).

One benefit that technology has afforded online assessment is the ability for social interaction and discussion, which gives students the opportunity to interact with assessors without being influenced by the responses of their peers (Benson 2003). The provision of immediate feedback to students is another benefit of online assessment, which is associated with flexibility for learners. In comparison to the scoring and evaluation of tests that involve extensive manual effort, online assessment offers savings in cost and time when enabled by assessment software, as well as the immediacy of delivering assessments wherever and whenever they are needed (Hricko and Howell 2006; Fluck 2019).

One of the main challenges of online assessment revolves around the subject of academic integrity and the associated issues of identity security, plagiarism, unauthorised collaboration (collusion) and cheating. Although these problems also exist in the traditional 
learning environment, they are amplified in the online setting because instructors do not physically see the students and their surroundings, while many characteristics of online technology enhance the opportunity and temptation for dishonest behaviour (Rowe 2004). In addition, the literature also identifies heightened concerns about the validity and reliability of online assessment (Gaytan and McEwen 2007), its security and confidentiality (Brem 2002; Rowe 2004), the challenge of assessing online group interaction (Morley 2000), the steep learning curve of becoming an autonomous student (Liang and Kim 2004), and the logistical difficulties of keeping up with the changes, upgrades and technical challenges of online software and testing environments (Henderson 2001; Fluck 2019). Thus, given the challenges of academic integrity and learner identity in online assessment, oral assessments such as oral examinations might represent an attractive option.

Although this paper has identified cases of oral assessment application, as well as various forms of online assessment, the literature offers limited insight into how a stand-alone oral examination technique would be implemented in a course delivered wholly online. To our knowledge, only two studies have examined the use of oral examination in an online environment. Okada, Scott, and Mendonca (2015) present the findings of their study into the use of videoconferencing to conduct oral examinations in the form of vivas for 3,205 postgraduate law students over a period of four years. The assessment strategy included the submission of a final paper that had to be defended orally via an online viva. Involving 53 examiners, the main purpose of the oral assessment was to "confirm that the paper was the work of the submitting students... and probe their knowledge of the submitted work to "quality assure" the submission' (Okada et al. 2015, 231). The oral examination in this case served more of a confirmatory role, in part to combat problems of academic dishonesty. The results show that although some students believed the online examination did not give them the opportunity to showcase their level of knowledge, others preferred this format because it 
provided flexibility in attendance and led to increased confidence and less stress than a faceto-face examination. From the institution's perspective, the benefits included cost savings in comparison to face-to-face vivas, flexibility, and the availability of instant feedback.

Similarly, Sotiriadou et al. (2019) applied an oral examination conducted via a virtual classroom to 22 students enrolled in an international management course. The scaffolded assessment strategy involved an interactive oral assessment in which students interviewed a client for whom a previous assessment report had been written. The results showed that students perceived oral examinations as developing and enhancing their communication skills and, given the interactive nature of the assessment, practically eliminating opportunities for academic dishonesty (Sotiriadou et al. 2019). In their conclusion, Sotiriadou et al. (2019) note that further research needs to be conducted on other postgraduate business disciplines to determine the applicability of oral examinations in multiple and complex assessment designs, and to validate the suitability of oral examination in an online environment.

\section{A case study of online oral examination}

The study presented in this paper is based on the experience of teaching a postgraduate finance course delivered purely online in an accelerated six-week format at an Australian university. The course resources consisted of videos, interactive online exercises and independent study tasks for all relevant topics, together with mock assessment exercises/quizzes as a formative assessment tool. The Yammer social media platform was used as a means of interaction among students and between students and staff, in addition to traditional emails and announcements on the course's Blackboard Learn (Blackboard Inc., Washington DC, USA) application website. 


\section{Description of the assessment dilemma}

In designing the assessment strategy for this postgraduate course, a variety of aspects were taken into consideration. The course focuses on the development of strong technical skills in the subject area, with students expected to learn how to apply their knowledge to practical problems and show their ability to analyse and synthesise relevant information. Thus, the assessment had to clearly reflect the testing of higher-order skills. Furthermore, the assessment had to incorporate a variety of assessment types to recognise the diverse ways students learn and to provide appropriate blocks to potential acts of academic dishonesty. Finally, all assessment items had to reflect the technical constraints of the online environment and be cost-effective too.

A review of online assessment practices (Rovai 2000; Robles and Braathen 2002; Gikandi, Morrow, and Davis 2011) reveals that the dominant form of assessment has been the written essay. In essays, students undertake some evaluation of certain ideas, solve certain practical problems, or provide an account of a background literature review for a particular research agenda. These types of assignment are often linked to major topics in the course and provide many benefits to the students. They are flexible, because students are typically afforded some time to complete the assessment, choosing their own time and environment in which to achieve the tasks most effectively. If properly designed, the assignments focus on one or more topics covered in the subject and test what they are supposed to test. They can be linked to the development of written communication skills, analytical or numerical abilities, research skills and/or the ability to synthesise existing information in a given scenario, and collaboration skills in the case of group projects. On the other hand, if the assessment task is targeting the development of certain individual skills that are similar across the student cohort, it presents a significant opportunity for academic dishonesty, where students do not complete their tasks independently, which includes the growing problem of contract cheating. 
Furthermore, a limited range of skills is targeted by this type of assessment, with other important skills such as oral communication or the ability to work under pressure not being well-covered. In addition, it can be extremely difficult to design assignments that cover all relevant topics of a course, leading to content being left untested and, ultimately, ignored by students in their independent studies. As with most written assessments, students have limited or no opportunity to elaborate further on their submitted work. Finally, written assignments can take a long time to mark, leading to increased costs for the faculty if the assessment strategy involves many such reports.

Although written assignments are considered useful, an assessment strategy should incorporate other types of assessment, for example, oral assessments, to test the learning outcomes that written assignments cannot address. When designing course assessment, instructors might sometimes have to consider other factors besides the purely pedagogical ones. Thus, in recent years, there has been an increasing trend for obtaining professional accreditations for courses, entire degrees or even whole schools (Akimov, Bianchi, and Drew 2014). The accrediting bodies may place additional constraints on how student learning and learning outcomes are achieved. For example, professional taxation bodies often require invigilated or proctored examinations as part of their accreditation requirements, which also suggests that invigilated examinations remain one of the most cost-effective tools for counteracting cheating and other forms of academic dishonesty.

\section{Design of the assessment strategy and rationale}

During the review of the potential assessment approaches considered for this course, oral examination was identified as a promising option. However, as evident from Table 1, the practice is rarely implemented in English-speaking higher education, aside from the viva voce for major research projects, although oral presentations are often used in assessment when the development of oral communication skills is defined as a significant priority. Oral 
presentations are also evident in the online education environment, although pre-recorded presentations/videos offer more flexibility to both students and markers, albeit at the expense of the ability to ask follow-up questions. However, as discussed earlier, there is little literature that explores the application of oral examination to online courses. Therefore, as an experiment, the decision was made to incorporate an oral examination into the assessment strategy for our course. The design of the oral assessment was carefully considered in terms of how it complemented the rest of the assessment and how it addressed the desired learning outcomes. In addition, the oral examination had to provide an opportunity for reflection on its implementation, benefits and challenges to both students and instructors. To address this, student surveys were prepared to gather their experiences of the oral examination.

Overall, the assessment strategy for the course consisted of three assessment items. A small formative assessment piece in the form of an online quiz was set early in the course (Week 3), consisting of 45 randomly drawn multiple-choice questions. The quiz covered the material taught in the first two weeks of the course and was designed to track how students were coping with the content, as well as creating an opportunity to reset the study strategy for the remainder of the course, if required.

The second assessment item was an applied project in which students had to undertake the analysis of a financial bond. This included estimating the bond's value, evaluating its interest rate risk using duration and convexity calculations, carrying out estimation of credit risk, and commenting on the possibility of credit rating changes. To provide an authentic assessment experience, each student had a unique bond to analyse, with basic information, bond description and quote, as well as three major financial statements sourced from Bloomberg terminals. To address a potential problem of inter-case reliability, all students were asked to apply the same analytical tools to their work. Because this course was not targeting group-working skills, a maximum of 36 hours was allocated for completion of the 
project, which served to minimise collaboration among students. The purpose of the assessment was to test individuals on the major practical concepts taught in the course, via an assessment of higher-order learning skills such as problem-solving and the application, analysis and evaluation of information.

The final assessment item in the course was the oral examination, which was designed to serve three major goals: first, to provide a good approach for testing an in-depth knowledge of the theoretical concepts of the course; second, to complement the applied project, which asked students to follow up/interpret some of the manipulations they had performed in the bond analysis; third, to contribute to the development of students' oral communication skills. Similarly to Okada et al. (2015), the second of these goals also served as a tool to counteract contract cheating in the preceding written assessment item. To assist students in their preparations for the oral examination, a list of 69 questions, reflecting major learning outcomes of every module, were distributed at the start of the course. Furthermore, before each week's live interactive session, students had to prepare answers to relevant questions. During those sessions, students were asked to discuss selected questions from the list associated with that week's topic, and were encouraged to actively participate and to practice their responses.

The online oral examination was run in 30-minute blocks for each student and was worth 40 per cent of the total grade. Two days were allocated for the entire examination, and students selected their preferred time-slot and date on a 'first-come, first-served' basis. During the online oral examination, students were first asked two randomly drawn theoretical questions from the list, with a target of around five minutes' response time for each. Then, around five minutes were allocated to a question related to the applied project, where students were asked to interpret some of their calculations and explain their approach. A further five to ten minutes were allocated for follow-up questions, and the remaining five minutes of the 30 
were used to provide brief feedback to the student and assign a mark. To avoid potential delays in the process, the mark associated with the online oral examination was not communicated to the student during the interview. Instead, the instructor completed a short online rubric-based form immediately after the conclusion of each interview, releasing the results shortly after all examinations had been completed and moderated. To ensure an effective identification process, at the start of the examination each student had to show the examiner a current student ID card or a government-issued document such as a passport or driver's licence to reduce opportunities for academic dishonesty.

The oral examination rubric contained four criteria: completeness of responses $(40 \%$ weighting), accuracy of responses (40\% weighting), overall depth and breadth of knowledge (10\% weighting), and oral communication skills (10\% weighting). As the criteria indicate, most weight was assigned to a student's ability to answer the questions accurately and comprehensively. However, the opportunity for the examiner to ask follow-up questions assisted in clarifying a student's breadth and depth of knowledge. As Pearce and Lee (2009, 122) suggest, oral examinations 'let examiners discriminate between superficial knowledge via in-depth questioning'. Development of oral communication was encouraged by assigning some weight to it in the examination marking criteria. The format of the oral examination encouraged students to practice 'thinking on their feet' and to develop their oral communication skills. Both skills are useful for job interviews, work meetings and, more broadly, in becoming articulate professionals (Buehler and Schneider 2009). To reduce the potential problem of intra-rater reliability, all online oral examinations were recorded and moderated by another finance academic. The moderator randomly selected examinations for review, while ensuring that the moderation sample included interviews that attracted high, medium and low marks. The moderator was satisfied with the standard of marking during the interviews. 


\section{Oral examination implementation and student feedback}

In this section, the experience of implementing the oral examination is discussed, starting with the analysis of pre- and post-examination confidential survey results, followed by the challenges, benefits and issues of administering oral examination as viewed by the instructors.

Investigating students' insights into the practice of oral examination is an area of assessment research that has been neglected (Joughin 2007). Thus, it is important to gather students' views from the point of view of research as well as from the perspective of good reflective teaching practice. Two voluntary confidential surveys were conducted to gather students' feedback, with appropriate ethical clearance obtained from the university's Ethics Committee. The first survey was initiated in the second week of the course after all assessment items had been explained in detail to the class. Of the 20 students enrolled in the course, 17 took part in this pre-examination survey. As evident from Table 2, for many students the experience of oral examination was either new or unfamiliar: $41 \%$ of students reported that they had not experienced oral examination or interview previously, while 59\% said that they had. It is unclear whether this latter experience was purely academic or whether some students had experienced such interviews in a professional context. All students confessed to being nervous about the oral assessment, with $94 \%$ stating that they would need to change their study approach to prepare for the oral examination.

[Insert Table 2 near here]

This relative lack of familiarity with oral examinations is also visible in students' preferences in terms of written or oral examination. Thus, $48 \%$ of students thought the written examination was a better option and only $24 \%$ indicated a preference for an oral examination. Nevertheless, 53\% agreed or strongly agreed that oral examination is an appropriate assessment method, with only $29 \%$ arguing against it. Importantly, $88 \%$ of students said they would invest at least as much effort in their preparation and study for the oral assessment as 
they would for a more traditional examination. The approach of explaining the nature of the assessment items to the students, together with a preparation strategy for the oral examination, appeared to be relatively successful, with most students ( $82 \%)$ being satisfied with both. This group of students showed great initiative and motivation in their desire to achieve good outcomes in the oral assessment. Thus, in response to students' requests, the instructor organised a series of mock online oral examination sessions in which students were able to provide feedback on each other's answers.

In the open question of the pre-examination survey, students were asked to outline their thoughts on the potential advantages and disadvantages of having an oral examination. Many confirmed their anxiety about the assessment; however, some pointed out the potential benefits of improving their communication skills: 'in the future ... this may be one of the only things a human can do in this particular industry that a computer cannot, as we can explain to the client why each strategy is better in less technical terms and with more personality. Therefore, presentation skills will be much more valued'. Students also noted that greater indepth knowledge is required to perform well in oral examinations, while others expressed the concern that the number of examined questions (69) was too large.

It is also interesting to explore how students' perceptions of oral assessment changed after the examination had been conducted. Table 3 presents the results from the 14 students who completed the post-examination survey and demonstrates feedback that is generally positive. Thus, most students agreed that the oral examination worked well in the online environment (79\%), was an effective way to test the course's learning outcomes (79\%), and paired well with the problem-solving assignment (86\%). When compared to a written examination, $43 \%$ of students felt that oral examination tested their knowledge better, $36 \%$ of respondents were neutral on this point, and $21 \%$ believed that a written examination would have tested their knowledge more. 
[Insert Table 3 near here]

Comparing similar question responses pre- and post-examination revealed some interesting results. There was a noticeable increase in those who thought oral examination to be an appropriate online assessment method, as illustrated in Figure 1. In line with the existing literature summarised in Table 1, we surmise that anxiety, and lack of knowledge and experience of oral assessment gave rise to the more negative results of the pre-examination survey. Once the students had undergone the oral examination, their perceptions regarding its appropriateness for online education improved.

\section{[Insert Figure 1 near here]}

Figure 2 compares the intended and actual efforts allocated to examination preparation. In the pre-examination survey, many students (53\%) indicated that they thought they would have to work harder to prepare for the oral examination, with only $12 \%$ claiming that they would study less than for a written examination. In reality, this did not manifest to the anticipated extent: $43 \%$ of students agreed that they worked harder, whereas a significant $29 \%$ said they studied less than they would have done for a written examination.

[Insert Figure 2 near here]

In the pre-examination survey, all students indicated that they were anxious to a certain extent about the prospect of taking an oral examination. After the fact, students admitted that they were, indeed, nervous: $42 \%$ stated that they were more nervous than they thought they would be, $43 \%$ were as nervous as they had anticipated, and only $14 \%$ felt they were less nervous than expected (see Figure 3).

[Insert Figure 3 near here]

The responses to the open question in the post-examination survey were predominantly positive. Students particularly valued the examination's conversational style, and they thought the exploratory and probing questions helped them perform better in the 
examination. Some students observed that the oral examination might pose a challenge to students with less-developed communication skills or those whose first language was not English. Also, on the negative side, students noted that they found the number of potential questions too demanding, and two students felt that luck had not been on their side having drawn questions for which they were less prepared.

From the instructor's perspective, several observations and reflections can be made. In general, the oral examination was delivered in an appropriate manner and proved to be a valid option for the online assessment strategy. Although there were no significant technical issues with the examination, there were a couple of brief instances of frozen communication links. Therefore, it is important to test the system well before the examinations are conducted. Because the instructor was also the only examiner, the administration and marking of the oral examination was a demanding and intensive experience. Although the overall marking time was comparable to that of a written examination, markers of written examinations typically have more flexibility in terms of when and where the marking is done.

Administering oral examinations for larger classes would present several additional challenges because it would either require multiple examiners, which in turn could raise interrater consistency issues, or the examinations would have to be scheduled over a longer period of time, which might not be practical. In general, therefore, this type of assessment will be more appropriate for smaller, more advanced classes. Obviously, the examiner must be sufficiently knowledgeable and competent to administer such examinations, particularly when it comes to asking follow-up and more probing questions. Although the moderator has not identified any biases in this instance, we recognise that certain biases in marking may arise from such live oral examination, with examiners finding it difficult to assign low scores, especially if students possess pleasant personalities. 
On the positive side, the intensity of the two-day examination period allowed the instructor to finalise the marking process in an expeditious manner. The examination's conversational style was also enjoyable for the instructor because it created a positive atmosphere during the process and allowed better understanding of the depth of students' knowledge via exploratory questions.

The course moderator randomly selected six recordings from the list of oral examinations conducted. To ensure intra-rater reliability, she viewed recordings from various times of the day and assessed the examination based on the course rubric. The moderator observed that the assessor attempted to make students feel comfortable and at ease with the answering of questions, and tried to draw out answers by asking probing and follow-up questions when students struggled. When students demonstrated the appropriate content knowledge the assessor did not need to lead or probe too much: students elaborated on their own and fully answered the questions. The moderator felt that the oral examination exhibited strong face and content validities in the sense that it tested what it was supposed to test and covered the field being studied. Moreover, construct validity was also addressed because both critical thinking and communication skills were tested. Finally, the moderator believed that, to some extent, concurrent validity was achieved as well; without knowing the cohort, she thought it likely that students who performed well in the oral examination had a good grasp of the content and thus would perform well in a written examination too.

\section{Discussion and conclusion}

Using Joughin's (1998) matrix, Table 4 shows how the case study of online oral examination presented here performs against the important criteria for good online assessment, that is, validity, reliability and fairness. Overall, the oral examination in the online context proves to be a high-quality assessment item with strong validity characteristics that also addresses some reliability criteria. Inter-item consistency, inter-case reliability and fairness are the measures 
for which it needs further attention and that can be addressed through careful assessment design.

\section{[Insert Table 4 near here]}

The technology available now makes it easier to deliver oral examination in the online environment smoothly. Technical courses, such as finance, typically define a range of learning outcomes, including knowledge of theory, the ability to undertake certain calculations and estimations, and interpretation of findings. It is acknowledged that not all of these can be tested well through an oral examination; thus, oral assessments should be applied intelligently to courses and more holistically in degree programmes. For technical subjects, an oral examination can work well in combination with other assessment items. Our course used a combination of an applied project and an oral examination to achieve a comprehensive assessment design. Furthermore, as well as testing more in-depth knowledge, oral examinations offer effective methods of developing additional skills, such as oral communication skills and the ability to think rapidly. These are valuable skills for any graduate, especially in the areas of business and social sciences. In addition, an oral examination can practically eliminate cheating in the assessment, which is a particularly important concern for courses delivered online.

The anxiety that students experience in relation to oral examination might, in part, be due to the fact that this assessment type remains rather rare in business schools. Greater familiarity with this mode of assessment will most likely reduce anxiety levels. Of similar importance is the training of academics in administering oral examinations in a friendly, conversational manner that encourages students to perform of their best.

The principal limitation of this study is the small number of students surveyed. One option to overcome this limitation in the future is to gather data from the same course over an extended period of time, although there could be challenges around consistency if the course 
structure, content and delivery evolve over time. Gathering data from multiple courses could be another solution if this innovative assessment method becomes more widely adopted. To date, however, the use of this practice remains limited. Finally, attempts might be made to introduce online oral examination into a larger online course. As discussed in a previous section, in its current form this assessment might pose additional challenges for a larger course. Instead, a modified version of examination might be used, for example, in the form of 'robo-examination', where a student's recorded response to a randomly selected set of questions is subsequently marked by examiners. This would unlikely to lower overall marking load but could help to partially overcome problems of timing and consistency, while maintaining many good features of the online oral examination described. However, such an assessment would forfeit the important interactivity component.

Overall, our study could have an important implication for all schools and faculties, not just in the business/commerce domain, when considering the design of their programmes and courses if combined learning outcomes, assurance of learning demands, and academic integrity policies are to be met. At the same time, realigning the staff culture towards the promotion and encouragement of the practice of oral examination as an authentic assessment tool may lead to a better outcome not just for students but for all stakeholders. 


\section{References}

Akimov, A., R. Bianchi, and M. Drew. 2014. "The academy-profession nexus in CFA partner programs." Journal of International Education in Business 7(2): 121-136.

Akimov, A., S. Kobinger, and M. Malin. 2018. "Determinants of student success in finance courses." Journal of Financial Education 44(2): 223-245.

Benson, A. 2003. "Assessing participant learning in online environments." New Directions for Adult and Continuing Education 2003(100): 69-78.

Bhati, S. 2012. "The effectiveness of oral presentation assessment in a Finance subject: An empirical examination." Journal of University Teaching \& Learning Practice 9(2). Available at: http://ro.uow.edu.au/jutlp/vol9/iss2/6

Biggs, J., and C. Tang. 2007. Teaching for quality learning at university. Maidenhead, UK: Open University Press/McGraw-Hill Education.

Borin, N., L. Metcalf, and B. Tietje. 2008. "Implementing assessment in an outcome-based marketing curriculum." Journal of Marketing Education 30(2): 150-159.

Brem, S. 2002. "Analysing online discussions: Ethics, data, and interpretation." Practical Assessment, Research \& Evaluation, 8(3). Available at: http://PAREonline.net/getvn.asp? $\mathrm{v}=8 \& n=3$

Buehler, M., and L. Schneider. 2009. "Speak up! Oral examinations and political science." Journal of Political Science Education 5(4): 315-331.

Dawson, P. 2016. "Five ways to hack and cheat with bring-your-own-device electronic examinations.” British Journal of Educational Technology 47(4): 592-600.

Fluck, A. E. 2019. “An international review of eExam technologies and impact." Computers \& Education 132: 1-15.

Gaytan, J., and B. McEwen. 2007. "Effective online instructional and assessment strategies." American Journal of Distance Education 21(3): 117-132.

Gikandi, J., D. Morrow and N. Davis. 2011. "Online formative assessment in higher education: A review of the literature." Computers \& Education 57(4): 2333-2351

Haque, M., R. Ibtisam, T. Mustafa, S. Qayyum, Q. Tahir, S. Melsing, and F. Rafique. 2016. "Oral examinations: What medical students and examiners think! Comparison of opinions on oral examination." International Journal of Pathology 14(2): 66-73.

Hargreaves, E. (2007). "The validity of collaborative assessment for learning. Assessment in education: principles." Policy \& Practice 14(2): 185-199. 
Henderson, T. 2001. "Classroom assessment techniques in asynchronous learning networks." The Technology Source September/October. Available at: http://ts.mivu.org/default.asp?show=article\&id=1034

Hricko, M., and S. Howell. 2006. Online assessment and measurement: Foundations and challenges. Hershey, PA \& London: Information Science Publishing.

Huxham, M., F. Campbell, and J. Westwood. 2012. “Oral versus written assessments: A test of student performance and attitudes." Assessment and Evaluation in Higher Education 37(1): 125-136.

Iannone, P., and A. Simpson. 2012. "Oral assessment in mathematics: Implementation and outcomes." Teaching Mathematics and its Applications 31(4): 179-190.

Joughin, G. 1998. "Dimensions of oral assessment.” Assessment and Evaluation in Higher Education 23(4): 367-378.

Joughin, G. 2007. "Student conceptions of oral presentations.” Studies in Higher Education 32(3): $323-336$.

Joughin, G. 2010. A short guide to oral assessment. Leeds, UK: Leeds Met Press in association with University of Wollongong. Available at: https://www.researchgate.net/publication/228844594_A_Short_Guide_to_Oral_Asses sment

Kehm, B. 2001. "Oral examinations in German universities.” Assessment in Education 8(1): $25-31$.

Liang, X., and C. Kim. 2004. "Classroom assessment in web-based instructional environment: Instructors' experience.” Practical Assessment, Research \& Evaluation 9(7). Available at: http://PAREonline.net/getvn.asp?v=9\&n=7

Lim, E. C. H., B. K. C. Ong, E. P. V. Wilder-Smith, and R. C. S. Seet. 2006. “Computerbased versus pen-and-paper testing: Students' perception." Annals Academy of Medicine Singapore 35(9): 599-603.

Morley, J. 2000. "Methods of assessing learning in distance education courses." Education at a Distance 13(1): 1-8.

Murillo-Zamorano, L. R., and M. Montanero. 2018. "Oral presentations in higher education: A comparison of the impact of peer and teacher feedback." Assessment \& Evaluation in Higher Education 43(1): 138-150. 
Oakley, B., and C. Hencken. 2005. "Oral examination assessment practice: Effectiveness and change with a first year undergraduate cohort." Journal of Hospitality, Leisure, Sports and Tourism Education 4(1): 3-14.

Okada, A., M. Mendonca, and P. Scott. 2015. "Effective web videoconferencing for proctoring online oral exams: A case study at scale in Brazil.” Open Praxis 7: 227242.

Oosterhof, A., R. Conrad, and D. Ely. 2008. Assessing learners online. Upper Saddle River, NJ: Pearson.

Pearce, G., and G. Lee. 2009. "Viva voce as an assessment method: Insights from marketing students." Journal of Marketing Education 31(2): 120-130.

Peet, A. (2016). “Efficiency or quality? Or both?” In G. Ferrell (Ed.), Online exams: Migration or transformation? JISC-EUNIS. Webinar held 21 Sep 16. Available at: https://www.youtube.com /watch?v=MjMNanbMpMQ

Rawls, J., A. Wilsker, and R. Rawls. 2015. “Are you talking to me? On the use of oral examinations in undergraduate business courses." Journal of the Academy of Business Education 16: 22-33.

Robles, M., and S. Braathen. 2002. “Online assessment techniques.” Delta Pi Epsilon Journal 44(1): 39-49.

Rovai, A. P. 2000. “Online and traditional assessments: What is the difference?" Internet and Higher Education 3(3): 141-151.

Rowe, N. 2004. "Cheating in online student assessment: Beyond plagiarism." Online Journal of Distance Learning Administration 7(2): 1-10.

Rytkönen, A., and L. Myyry. 2014. "Student experiences on taking electronic exams at the University of Helsinki." In Proceedings of World Conference on Educational Multimedia, Hypermedia and Telecommunications 2014 Tampere, Finland, 24/06/2014 (pp. 2114-2121). Waynesville, NC: Association for the Advancement of Computing in Education. Available at: https://helda.helsinki.fi/bitstream/handle/10138/158506/edmedia2014_StudentExperie nces_Rytkonen_Myyry.pdf?sequence=1

Sotiriadou, P., D. Logan, A. Daly, and R. Guest. 2019. "The role of authentic assessment to preserve academic integrity and promote skill development and employability.” Studies in Higher Education, DOI: 10.1080/03075079.2019.1582015. 
Xiong, Y., and H. K. Suen. 2018. "Assessment approaches in massive open online courses: Possibilities, challenges and future directions." International Review of Education 64(2): 241-263. 
Table 1. Summary of oral assessment literature.

\begin{tabular}{|c|c|c|c|c|}
\hline Publication & Strategy & Benefits & Challenges & Other comments \\
\hline $\begin{array}{l}\text { Haque et al. } \\
(2016)\end{array}$ & $\begin{array}{l}\text { Survey of } 347 \text { medical students } \\
\text { and } 30 \text { examiners from three } \\
\text { public and two private medical } \\
\text { colleges to compare opinions of a } \\
\text { traditional oral examination } \\
\text { (TOE) system. }\end{array}$ & $\begin{array}{l}\text { From the students' perspective, } \\
\text { TOE enhanced communication } \\
\text { skills, knowledge and confidence. } \\
\text { Faculty perceived TOE as time- and } \\
\text { cost-effective, and a better } \\
\text { evaluator of verbal, theoretical and } \\
\text { decision-making skills. }\end{array}$ & $\begin{array}{l}\text { High pre-examination anxiety was } \\
\text { reported by } 42 \% \text { of students, of which } \\
98 \% \text { were female. } \sim 41 \% \text { of students } \\
\text { believed that more practice oral } \\
\text { examinations were needed, while } 76 \% \\
\text { thought course topics were not evenly } \\
\text { covered in the assessment. } \\
\text { Half of both students and examiners } \\
\text { felt that scoring became more lenient } \\
\text { as the examination day progressed. }\end{array}$ & $\begin{array}{l}\text { None of the } 30 \text { examiners } \\
\text { surveyed had any training on } \\
\text { how to conduct oral } \\
\text { examinations. } \\
\text { A large number of examiners } \\
\text { acknowledged the presence of } \\
\text { various biases, such as } \\
\text { appearance and language, in } \\
\text { awarding a grade. }\end{array}$ \\
\hline $\begin{array}{l}\text { Rawls, Wilsker } \\
\text { and Rawls (2015) }\end{array}$ & $\begin{array}{l}\text { Oral examination was applied in } \\
\text { undergraduate Management and } \\
\text { Economics courses. Each student } \\
\text { had one question to be answered } \\
\text { within seven minutes. One } \\
\text { assessor graded all answers, using } \\
\text { a rubric. Students were surveyed } \\
\text { immediately after the examination } \\
\text { and interviewed later to seek } \\
\text { feedback regarding the process. }\end{array}$ & $\begin{array}{l}\text { Students reported relating better to } \\
\text { the course content after the oral } \\
\text { examinations, which supports } \\
\text { knowledge reinforcement through } \\
\text { this kind of assessment. } \\
\text { Some students studied more for the } \\
\text { oral exam, relative to a written one, } \\
\text { while others reported studying } \\
\text { about the same. From the latter } \\
\text { group, } 59 \% \text { reported learning more. }\end{array}$ & $\begin{array}{l}\text { Level of anxiety was higher for } \\
\text { Management than Economics students. }\end{array}$ & $\begin{array}{l}\text { Appropriate oral examination } \\
\text { structure led to a professional } \\
\text { and considerate process. } \\
\text { Practising before the } \\
\text { examination } \\
\text { and verbalising the potential } \\
\text { answers helped students retain } \\
\text { and learn more. }\end{array}$ \\
\hline Bhati (2012) & $\begin{array}{l}\text { Oral presentation worth } 10 \% \text { as } \\
\text { part of group work assessment in } \\
\text { a Finance postgraduate course. } \\
\text { Presentation assessed mostly } \\
\text { communication skills with content } \\
\text { knowledge only forming a small } \\
\text { component of presentation. }\end{array}$ & $\begin{array}{l}\text { Oral presentations helped improve } \\
\text { English language and presentation } \\
\text { skills and reduced the likelihood of } \\
\text { cheating. }\end{array}$ & $\begin{array}{l}\text { International students and those with } \\
\text { English as a second language could be } \\
\text { disadvantaged by oral assessment. }\end{array}$ & $\begin{array}{l}\text { Overall, students achieved better } \\
\text { scores in a written group report } \\
\text { than in the individual oral } \\
\text { presentation. } \\
\text { Male students performed better } \\
\text { than female students in oral } \\
\text { presentation. }\end{array}$ \\
\hline $\begin{array}{l}\text { Huxham, } \\
\text { Campbell and } \\
\text { Westwood (2012) }\end{array}$ & $\begin{array}{l}\text { Oral and written examination was } \\
\text { conducted in a Biology course on } \\
\text { two separate student cohorts. } 15- \\
\text { minute one-on-one oral } \\
\text { examination for } 45 \text { students and } \\
30 \text {-minute written examination for } \\
46 \text { students. }\end{array}$ & $\begin{array}{l}\text { Students found oral assessment } \\
\text { more useful than written assessment } \\
\text { and valued the opportunity to } \\
\text { practice interview skills. Dyslexic } \\
\text { students favoured oral } \\
\text { examinations. }\end{array}$ & $\begin{array}{l}\text { Students taking the oral examination } \\
\text { experienced higher anxiety than those } \\
\text { taking the written test. }\end{array}$ & $\begin{array}{l}\text { Orally assessed students } \\
\text { performed better than those in } \\
\text { the written exam, results that } \\
\text { were consistent between year } \\
\text { groups and type of questions } \\
\text { asked. }\end{array}$ \\
\hline
\end{tabular}




\begin{tabular}{|c|c|c|c|c|}
\hline $\begin{array}{l}\text { Iannone and } \\
\text { Simpson (2012) }\end{array}$ & $\begin{array}{l}\text { First-year Pure Mathematics } \\
\text { course introduced a } 10 \text {-minute } \\
\text { oral assessment, called 'one-on- } \\
\text { one' tutorial, worth } 10 \% \text { of the } \\
\text { total mark. Students were given } \\
\text { four questions in advance, had to } \\
\text { answer one question of their } \\
\text { choice and one question chosen } \\
\text { by the assessor, and had the } \\
\text { opportunity to write on board or } \\
\text { paper the solutions they were } \\
\text { discussing. A mark was awarded } \\
\text { based on a matrix that was shared } \\
\text { with the students in advance. }\end{array}$ & $\begin{array}{l}\text { Through discussion, students could } \\
\text { work out the solutions even if there } \\
\text { was a gap or misunderstanding in } \\
\text { their knowledge. Assessors could } \\
\text { determine whether students } \\
\text { understood their answer and give } \\
\text { partial marks for appropriate levels } \\
\text { of information presented. }\end{array}$ & $\begin{array}{l}\text { High level of anxiety and stress } \\
\text { associated with the oral assessment. } \\
\text { Students felt that the } 10 \text {-min oral was } \\
\text { rushed and there was not enough } \\
\text { opportunity to seek clarification. } \\
\text { Some students preferred the traditional } \\
\text { final written exam. }\end{array}$ & $\begin{array}{l}\text { Students found the experience } \\
\text { very rewarding as the process of } \\
\text { explaining the solutions gave } \\
\text { them a sense of achievement. } \\
\text { They also valued the extensive } \\
\text { feedback from assessors in the } \\
\text { oral form of assessment as } \\
\text { compared to just receiving a } \\
\text { grade allocation on a written } \\
\text { exam. } \\
\text { Overall, students appreciated the } \\
\text { diversity in assessment and saw } \\
\text { the benefit of interaction and } \\
\text { engagement in class. }\end{array}$ \\
\hline $\begin{array}{l}\text { Buehler and } \\
\text { Schneider (2009) }\end{array}$ & $\begin{array}{l}\text { Oral examination as a final } \\
\text { assessment for } 125 \text { students } \\
\text { enrolled in Political Science } \\
\text { courses over four semesters, run } \\
\text { over two days. Each student was } \\
\text { asked } 4-5 \text { randomly selected } \\
\text { questions from a bank and had } 15 \\
\text { minutes to answer. } \\
\text { Examination is administered one- } \\
\text { on-one, closed book, closed door. } \\
\text { No two students receive the same } \\
\text { questions. }\end{array}$ & $\begin{array}{l}\text { Students had the opportunity to } \\
\text { clarify and provide more in-depth } \\
\text { responses. } \\
\text { Instructors were able to ask follow- } \\
\text { up questions that allowed students } \\
\text { to demonstrate their knowledge and } \\
\text { understanding. } \\
\text { Elimination of academic } \\
\text { dishonesty. }\end{array}$ & $\begin{array}{l}\text { Instructors in large classes need more } \\
\text { time to administer the oral exam. } \\
\text { High level of student anxiety during } \\
\text { the oral exam, denoted by fidgeting, } \\
\text { tapping, inability to maintain eye } \\
\text { contact and asking to have the } \\
\text { questions repeated many times. }\end{array}$ & $\begin{array}{l}\text { Before taking the oral exam, } \\
\text { students verbalised their } \\
\text { concerns and anxiety because it } \\
\text { was something they had never } \\
\text { done before. } \\
\text { During the exam, students } \\
\text { relaxed, and they were surprised } \\
\text { at how well they handled } \\
\text { 'thinking on their feet'. After the } \\
\text { exam, students gained } \\
\text { confidence and were more active } \\
\text { in class. }\end{array}$ \\
\hline $\begin{array}{l}\text { Pearce and Lee } \\
(2009)\end{array}$ & $\begin{array}{l}\text { Oral examination (viva) worth } \\
40 \% \text { instead of final examination } \\
\text { for final-year students in a } \\
\text { Marketing elective course. Each } \\
\text { student was allocated a } 20 \text {-minute } \\
\text { interview, with performance } \\
\text { assessed on a 5-point Likert scale } \\
\text { across } 12 \text { criteria that included } \\
\text { knowledge of subject and } \\
\text { application of theory to practice. }\end{array}$ & $\begin{array}{l}\text { Assessment through viva was } \\
\text { considered superior to written } \\
\text { examination in determining student } \\
\text { knowledge; it encouraged } \\
\text { understanding of subject matter and } \\
\text { enabled demonstration of problem- } \\
\text { solving skills; it prepared students } \\
\text { for the workplace by enhancing } \\
\text { communication skills. }\end{array}$ & $\begin{array}{l}\text { Difficulty with planning and staging } \\
\text { the oral examinations, which required } \\
\text { additional hours and resources. } \\
\text { Reliability and validity issues as well } \\
\text { as examiner bias. High anxiety } \\
\text { associated with oral examination, } \\
\text { which can be reduced by having more } \\
\text { practice sessions during the semester, } \\
\text { briefing students about the process, and } \\
\text { incorporating this type of assessment } \\
\text { into other courses. }\end{array}$ & $\begin{array}{l}\text { Students considered oral } \\
\text { examination an interactive } \\
\text { experience and a better form of } \\
\text { assessment. The process gave } \\
\text { students a chance to elaborate } \\
\text { and expand on the topic and } \\
\text { think more critically, as well as } \\
\text { allowing for spontaneous } \\
\text { answers. }\end{array}$ \\
\hline
\end{tabular}




\begin{tabular}{|c|c|c|c|c|}
\hline $\begin{array}{l}\text { Oakley and } \\
\text { Hencken (2005) }\end{array}$ & $\begin{array}{l}\text { Pilot study of implementing oral } \\
\text { examination in four courses of an } \\
\text { undergraduate Sports degree. For } \\
\text { each unit, a } 10 \text { - to } 20 \text {-question } \\
\text { bank was prepared, with } \\
\text { responses graded on a } 0-5 \text { scale. } \\
\text { Students attended the oral in } \\
\text { predetermined groups of three, } \\
\text { were allocated a } 30 \text {-minute period } \\
\text { for the assessment, and each had } \\
\text { to answer two questions on three } \\
\text { learning outcomes, giving a total } \\
\text { of six per student. The examiners } \\
\text { consisted of a six-tutor panel, in } \\
\text { which two acted as moderators. }\end{array}$ & $\begin{array}{l}\text { Students agreed that oral } \\
\text { assessment prepared them better for } \\
\text { the workplace than written exams. } \\
\text { Female students were better } \\
\text { motivated to prepare for the oral } \\
\text { assessment. } \\
\text { Deemed to have greater educational } \\
\text { impact because oral examinations } \\
\text { can evaluate how well students } \\
\text { apply knowledge rather than } \\
\text { presenting memorised facts. }\end{array}$ & $\begin{array}{l}\text { Limiting the oral examination to just } \\
\text { six questions did not offer a great } \\
\text { opportunity for students to showcase } \\
\text { their knowledge and gain marks. Lack } \\
\text { of uniformity in the difficulty level of } \\
\text { the questions. Considerable time and } \\
\text { effort was applied to developing the } \\
\text { question bank, in particular, phrasing } \\
\text { the questions in such a way as to lead } \\
\text { to an open response. Less-confident } \\
\text { students felt intimidated in responding } \\
\text { to questions in front of other students } \\
\text { and the panel. }\end{array}$ & $\begin{array}{l}\text { There was a lot of variation in } \\
\text { the student feedback in the } \\
\text { survey administered one month } \\
\text { after the oral examination; } \\
\text { however, overall, there were } \\
\text { more positive than negative } \\
\text { responses. Students felt that } \\
\text { mock examination preparation } \\
\text { and level of questions used were } \\
\text { appropriate. } \\
\text { Performance in the written } \\
\text { assessment was a strong } \\
\text { predictor of performance in the } \\
\text { oral examination. Staff training } \\
\text { is essential in how to give non- } \\
\text { verbal cues that help and } \\
\text { encourage students. }\end{array}$ \\
\hline Kehm (2001) & $\begin{array}{l}\text { Summary of the practice of oral } \\
\text { examination at German } \\
\text { universities where, irrespective of } \\
\text { the degree (state, Diplom or } \\
\text { Magister), all include oral } \\
\text { assessment in addition to written } \\
\text { tests. Depending on the subject, } \\
\text { orals count for } 20-25 \% \text { of the } \\
\text { total marks and last } 20-60 \\
\text { minutes. The examination of } \\
\text { individual students is conducted } \\
\text { by two academic staff chosen by } \\
\text { the student, on a topic agreed by } \\
\text { student and examiner beforehand. }\end{array}$ & $\begin{array}{l}\text { Oral examination is regarded as a } \\
\text { complement to other forms of } \\
\text { assessment and an opportunity for } \\
\text { students to show their strengths and } \\
\text { their ability to reflect and think } \\
\text { critically. Through more detailed } \\
\text { questioning, the examiners can } \\
\text { distinguish superficial from real } \\
\text { knowledge. }\end{array}$ & $\begin{array}{l}\text { Perceived bias as to the examiner's } \\
\text { prejudice, dislike or disapproval of a } \\
\text { student as well as the examiner's } \\
\text { power to dictate how the process of } \\
\text { oral interview is conducted. } \\
\text { Furthermore, from a socio- } \\
\text { psychological view, oral examinations } \\
\text { can be regarded as oppressive and a } \\
\text { means of status allocation. As with } \\
\text { other studies, the issues of objectivity, } \\
\text { reliability and validity of oral } \\
\text { examinations are raised. }\end{array}$ & $\begin{array}{l}\text { The article quotes academics } \\
\text { who maintain that oral } \\
\text { examinations should be the } \\
\text { norm in all professional fields, } \\
\text { because through such } \\
\text { examinations a student's } \\
\text { personality is revealed and their } \\
\text { leadership capabilities are } \\
\text { demonstrated. }\end{array}$ \\
\hline
\end{tabular}


Table 2. Pre-oral examination survey.

\begin{tabular}{|c|c|c|c|c|c|}
\hline \multirow[t]{2}{*}{ Question } & \multicolumn{5}{|c|}{ Answer } \\
\hline & Yes & No & \multicolumn{3}{|c|}{ Have not accessed } \\
\hline $\begin{array}{l}\text { Have you ever taken an oral } \\
\text { examination/interview as an assessment? }\end{array}$ & $59 \%$ & $41 \%$ & \multicolumn{3}{|c|}{ N/A } \\
\hline $\begin{array}{l}\text { Do you think you will have to change the } \\
\text { approach/way you study in this course as a } \\
\text { result of having an oral examination? }\end{array}$ & $94 \%$ & $6 \%$ & \multicolumn{3}{|c|}{ N/A } \\
\hline $\begin{array}{l}\text { The description of the format of the oral } \\
\text { examination is listed in the course profile. } \\
\text { The list of examinable questions is available } \\
\text { from the course site. Moreover, the course } \\
\text { convenor has explained in detail the format } \\
\text { of the oral examination. Are you satisfied } \\
\text { with the level of detail provided about the } \\
\text { examination? }\end{array}$ & $82 \%$ & $18 \%$ & \multicolumn{3}{|c|}{$0 \%$} \\
\hline \multirow[t]{2}{*}{$\begin{array}{l}\text { In the online sessions the teacher will be } \\
\text { asking students questions from the week's } \\
\text { material. Do you think this is an appropriate } \\
\text { strategy to assist students preparing for the } \\
\text { oral exam? }\end{array}$} & $82 \%$ & $18 \%$ & \multicolumn{3}{|c|}{ N/A } \\
\hline & Very & Somewhat & & No & \\
\hline \multirow[t]{2}{*}{$\begin{array}{l}\text { Do you feel nervous about taking the oral } \\
\text { examination? }\end{array}$} & $53 \%$ & $47 \%$ & \multicolumn{3}{|c|}{$0 \%$} \\
\hline & $\begin{array}{c}\text { Strongly } \\
\text { agree }\end{array}$ & Agree & Neutral & Disagree & $\begin{array}{l}\text { Strongly } \\
\text { disagree }\end{array}$ \\
\hline $\begin{array}{l}\text { Oral examination is an appropriate method } \\
\text { of assessing students in the online } \\
\text { environment }\end{array}$ & $18 \%$ & $35 \%$ & $18 \%$ & $29 \%$ & $0 \%$ \\
\hline \multirow[t]{2}{*}{$\begin{array}{l}\text { I prefer to have a traditional invigilated } \\
\text { written examination in this course }\end{array}$} & $24 \%$ & $24 \%$ & $29 \%$ & $18 \%$ & $6 \%$ \\
\hline & $\begin{array}{l}\text { Much } \\
\text { more }\end{array}$ & More & The same & Less & Much less \\
\hline $\begin{array}{l}\text { Will the prospect of being directly } \\
\text { questioned and challenged encourage you to } \\
\text { prepare more or less thoroughly than for a } \\
\text { traditional exam? }\end{array}$ & $18 \%$ & $35 \%$ & $35 \%$ & $12 \%$ & $0 \%$ \\
\hline
\end{tabular}


Table 3. Post-oral examination survey

\begin{tabular}{|c|c|c|c|c|c|}
\hline \multirow[t]{2}{*}{ Question } & \multicolumn{5}{|c|}{ Answer } \\
\hline & $\begin{array}{l}\text { Strongly } \\
\text { agree }\end{array}$ & Agree & Neutral & Disagree & $\begin{array}{l}\text { Strongly } \\
\text { disagree }\end{array}$ \\
\hline $\begin{array}{l}\text { Oral examination worked well in the online } \\
\text { environment }\end{array}$ & $36 \%$ & $43 \%$ & $14 \%$ & $0 \%$ & $7 \%$ \\
\hline $\begin{array}{l}\text { The questions asked in the oral examination were } \\
\text { set at the appropriate level of difficulty }\end{array}$ & $43 \%$ & $36 \%$ & $21 \%$ & $0 \%$ & $0 \%$ \\
\hline $\begin{array}{l}\text { The oral examination was an effective way of } \\
\text { testing whether the course's learning outcomes } \\
\text { (aims) had been met }\end{array}$ & $29 \%$ & $50 \%$ & $7 \%$ & $7 \%$ & $7 \%$ \\
\hline \multirow[t]{3}{*}{$\begin{array}{l}\text { Having a problem-solving assignment coupled } \\
\text { with an oral examination worked well together to } \\
\text { comprehensively test your skills and knowledge in } \\
\text { the course }\end{array}$} & $36 \%$ & $50 \%$ & $14 \%$ & $0 \%$ & $0 \%$ \\
\hline & & & The & & \\
\hline & Much more & More & same & Less & Much less \\
\hline $\begin{array}{l}\text { Did the prospect of being directly questioned and } \\
\text { challenged encourage you to prepare more or less } \\
\text { thoroughly than for a traditional written exam? }\end{array}$ & $0 \%$ & $43 \%$ & $29 \%$ & $29 \%$ & $0 \%$ \\
\hline $\begin{array}{l}\text { Did you feel the oral examination tested your } \\
\text { knowledge more or less than a traditional written } \\
\text { exam? }\end{array}$ & $7 \%$ & $36 \%$ & $36 \%$ & $21 \%$ & $0 \%$ \\
\hline $\begin{array}{l}\text { Do you think that the oral examination is more } \\
\text { closely linked to the skills used in the workplace } \\
\text { than a traditional written exam? }\end{array}$ & $43 \%$ & $14 \%$ & $36 \%$ & $7 \%$ & $0 \%$ \\
\hline $\begin{array}{l}\text { Were you as nervous during the oral examination } \\
\text { as you anticipated? }\end{array}$ & $21 \%$ & $21 \%$ & $43 \%$ & $14 \%$ & $0 \%$ \\
\hline
\end{tabular}


Table 4. Oral examination validity, reliability and fairness matrix.

\begin{tabular}{|c|c|c|}
\hline Criterion & Evaluation & $\begin{array}{l}\text { Meets the } \\
\text { criterion }\end{array}$ \\
\hline Face validity & $\begin{array}{l}\text { In this case, students were tested for their depth of knowledge of the } \\
\text { subject and, to a lesser degree, their communication skills. It served } \\
\text { the purpose well. }\end{array}$ & Yes \\
\hline Content validity & $\begin{array}{l}\text { Students received questions from the pre-published list in a random } \\
\text { fashion. Comprehensive preparation requires coverage of all possible } \\
\text { questions. However, in the examination itself, luck plays a role; } \\
\text { students may face relatively harder or easier questions. Follow-up } \\
\text { questions help to overcome such potential inconsistencies. }\end{array}$ & Generally, yes \\
\hline Construct validity & $\begin{array}{l}\text { Through the probing and exploratory questions, the oral examination } \\
\text { helped to reveal deeper knowledge, beyond surface knowledge and } \\
\text { skills. }\end{array}$ & Yes, strongly \\
\hline $\begin{array}{l}\text { Concurrent } \\
\text { validity }\end{array}$ & $\begin{array}{l}\text { Students may exhibit some variation in performance if tested } \\
\text { differently, e.g. through written exam, due to more/less-developed } \\
\text { oral/written communication skills. However, the problem is unlikely } \\
\text { to be a significant one. }\end{array}$ & Generally, yes \\
\hline $\begin{array}{l}\text { Inter-item } \\
\text { consistency }\end{array}$ & $\begin{array}{l}\text { Because the draw of the questions is random, students may perform } \\
\text { better or worse depending on which questions they get. The mitigating } \\
\text { factor is that students knew the question set in advance and had an } \\
\text { equal opportunity to prepare for all questions. }\end{array}$ & Not completely \\
\hline $\begin{array}{l}\text { Inter-case } \\
\text { reliability }\end{array}$ & $\begin{array}{l}\text { It is hard to determine whether students perform significantly } \\
\text { differently if follow-up questions are different. The examiner tried } \\
\text { their best to get the best from each student. The degree to which they } \\
\text { succeeded is unknown. Training of examiners should reduce inter-case } \\
\text { reliability issues. }\end{array}$ & Not completely \\
\hline $\begin{array}{l}\text { Inter-rater } \\
\text { reliability }\end{array}$ & $\begin{array}{l}\text { This has not been a problem because all students were examined by } \\
\text { one person. }\end{array}$ & Yes \\
\hline $\begin{array}{l}\text { Intra-rater } \\
\text { reliability }\end{array}$ & $\begin{array}{l}\text { There might be some inconsistencies in whether the oral examinations } \\
\text { are marked earlier or later in the examination period. Therefore, } \\
\text { mitigating factors were set up to minimise the problem, including a } \\
\text { moderation process, and not releasing the marks until the conclusion } \\
\text { of the exam, so that the examiner can review their notes and compare } \\
\text { results across the board. }\end{array}$ & Generally, yes \\
\hline Fairness & $\begin{array}{l}\text { This assessment item does discriminate against students with poorer } \\
\text { command of English or a non-English-speaking background in a } \\
\text { similar way to other assessment types. Having an examiner with } \\
\text { experience of dealing with such students would be a partial mitigation } \\
\text { factor. The question set was of a broad theoretical and practical nature } \\
\text { and is unlikely to have favoured any particular group of students in a } \\
\text { systematic way. }\end{array}$ & Not completely \\
\hline
\end{tabular}




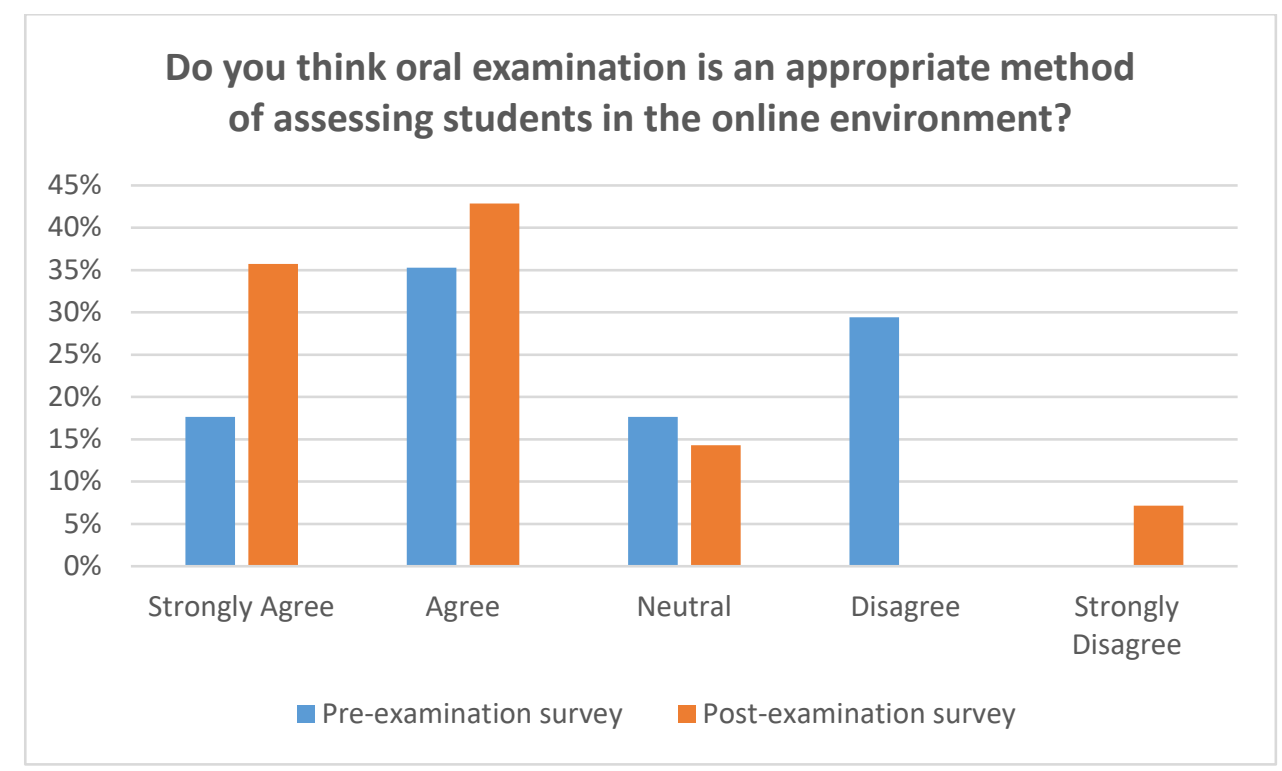

Figure 1. Comparison of pre- and post-oral examination perceptions of oral assessment.

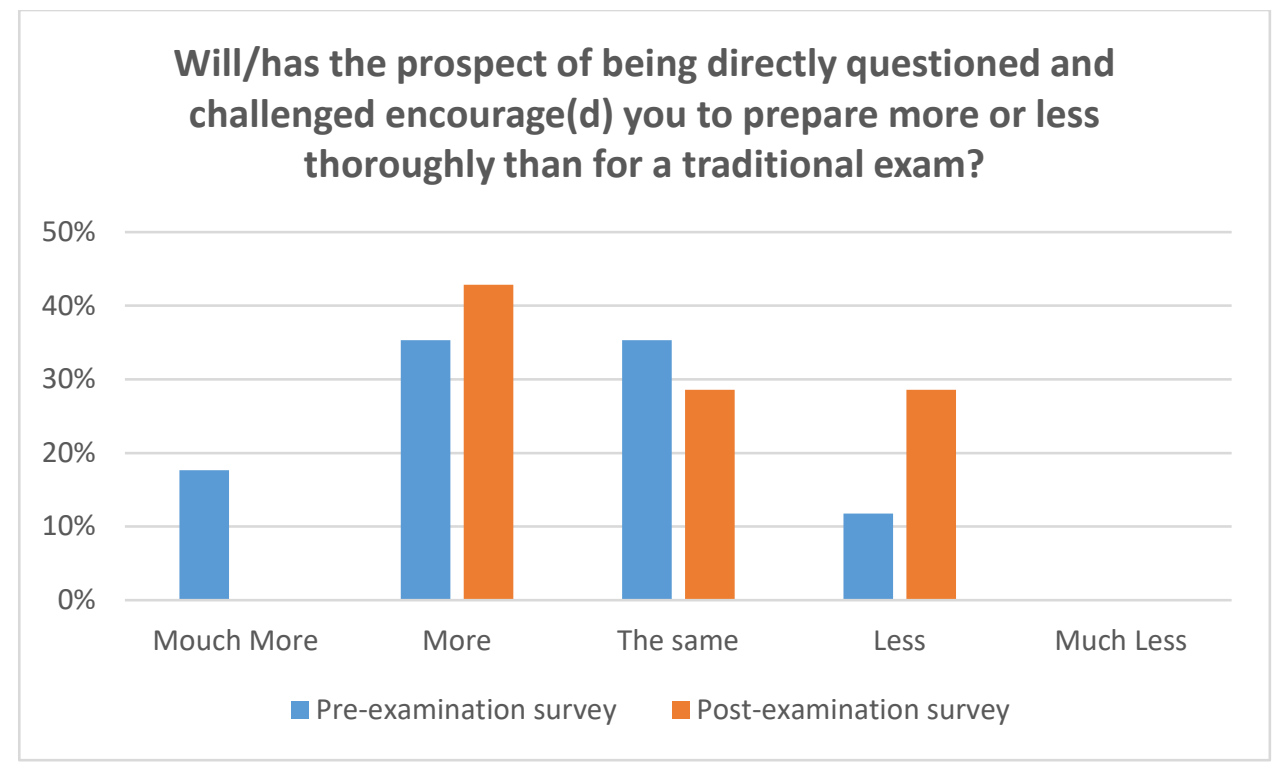

Figure 2. Comparison of intended and actual efforts in preparation for oral examination. 


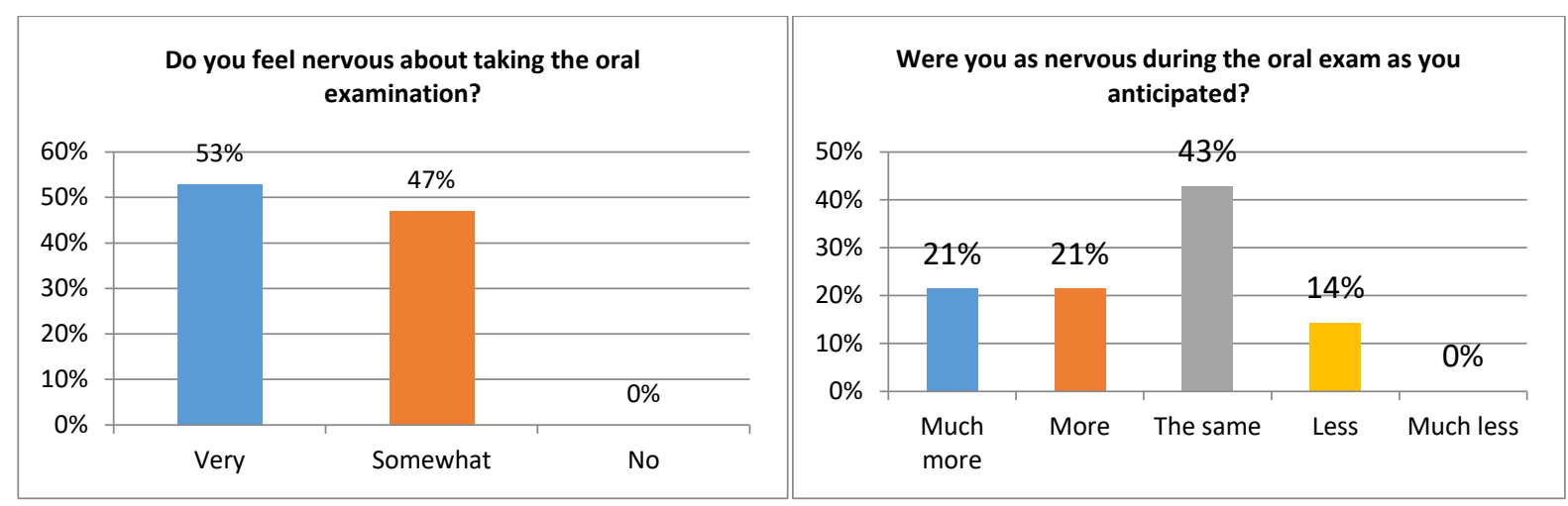

Figure 3. Students' anticipated and actual nervousness during the oral exam. 